\title{
Investment Analysis of Startups Company PT. Zaps Teknologi Service Application of BPJS
}

\author{
Zulham Wafiq ${ }^{1}$, Edi Hamdi ${ }^{2}$, Tantri Yanuar Rahmat Syah ${ }^{3}$, Rhian Indradewa ${ }^{4}$ \\ 1,2,3,4 Department Management, Faculty Economic and Business, Esa Unggul University, Jakarta - Indonesia \\ Corresponding Author: Zulham Wafiq
}

\begin{abstract}
Background - Health facilities and hospitals are government facilities in serving the community in the health sector, BPJS is one of the media used by the government in carrying out these services. PT. Zaps Teknologi is a company engaged in technology and information with the product of Dokter Tunggu (DOKU). This application was created to improve BPJS services in Hospitals and Health Facilities. The application has innovations in BPJS services where this application has features that are able to accommodate BPJS services. Online referrals, real time conditions from the Referral Hospital are some of the features embedded in this application, besides that in the next few years PT. Zaps Teknologi will improve services by adding features to this application. The addition of features requires detailed financial analysis and precise investment calculations
\end{abstract}

Method - Investment analysis using NPV, ROI, PP and IRR

Result - This analysis shows the investment value for investors in making investment decisions.

Keyword: Investment, BPJS, Financial Analysis

\section{BACKGROUND}

Providing good service is one form of promising service (Hanifatul et al., 2020). Good service in the public sector must have benefits for members of the community. One of them is services in the health sector which is one of the government services for the community. BPJS is a service in the health sector that covers all people in Indonesia, services to the community not only involve existing human resources, although excellent service can be provided if the existing workforce has high competence and motivation. In addition to the workforce, another service factor is technology that can be applied to services in health facilities or hospitals through online that are connected to the hospital management information system. (Royyadi and Nofierni, 2021) Innovation that continues to be developed for health facility services is one way that is expected to meet customer expectations and needs in developing people's lifestyles in Indonesia. PT. Zaps Teknologi makes an application for BPJS patients and has a functions to improve BPJS services at level I Health Facilities or Hospital.(Royyadi and Nofierni, 2021) With the number of hospitals as many as 2,813 spread throughout Indonesia, making it a large market share. The number of participants in the National Health Insurance (JKN) program organized by BPJS Health reached 222.5 million people as of December 31, 2020. This figure is equivalent to $81.3 \%$ of the population in Indonesia. In detail, the recipients of contribution assistance (PBI) from the APBN and APBD are 132.8 million people. Contributions for this category are paid by the government. Furthermore, there are 55.1 million wageearning workers (PPU), both civil servants and business entities, their contributions are deducted from their salaries. Lastly, independent participants consisting of nonwage workers (PBPU) as many as 30.4 
million people and non-workers (BP) as many as 4.1 million people. This amount requires services that are felt and enjoyed directly by customers and in accordance with expectations.

\section{MATERIALS AND METHOD}

The investment feasibility analysis is calculated with financial planning, the planning includes income planning, financing planning, capital needs planning and fulfilling capital needs (Kwarti et al.,
2020). Parameters calculated for investment feasibility for five years include Return on Investment, Net Present Value, Payback Period and Internal Rate of Return.(Prihambodo et at., 2020) The purpose of the investment calculation is to see to what extent the invested capital is profitable for investors and of course for other capital owners, as well as to determine the planning of financial investment strategies in the future.. (Hanifatul et. al., 2020)

\section{RESULT AND DISCUSSION}

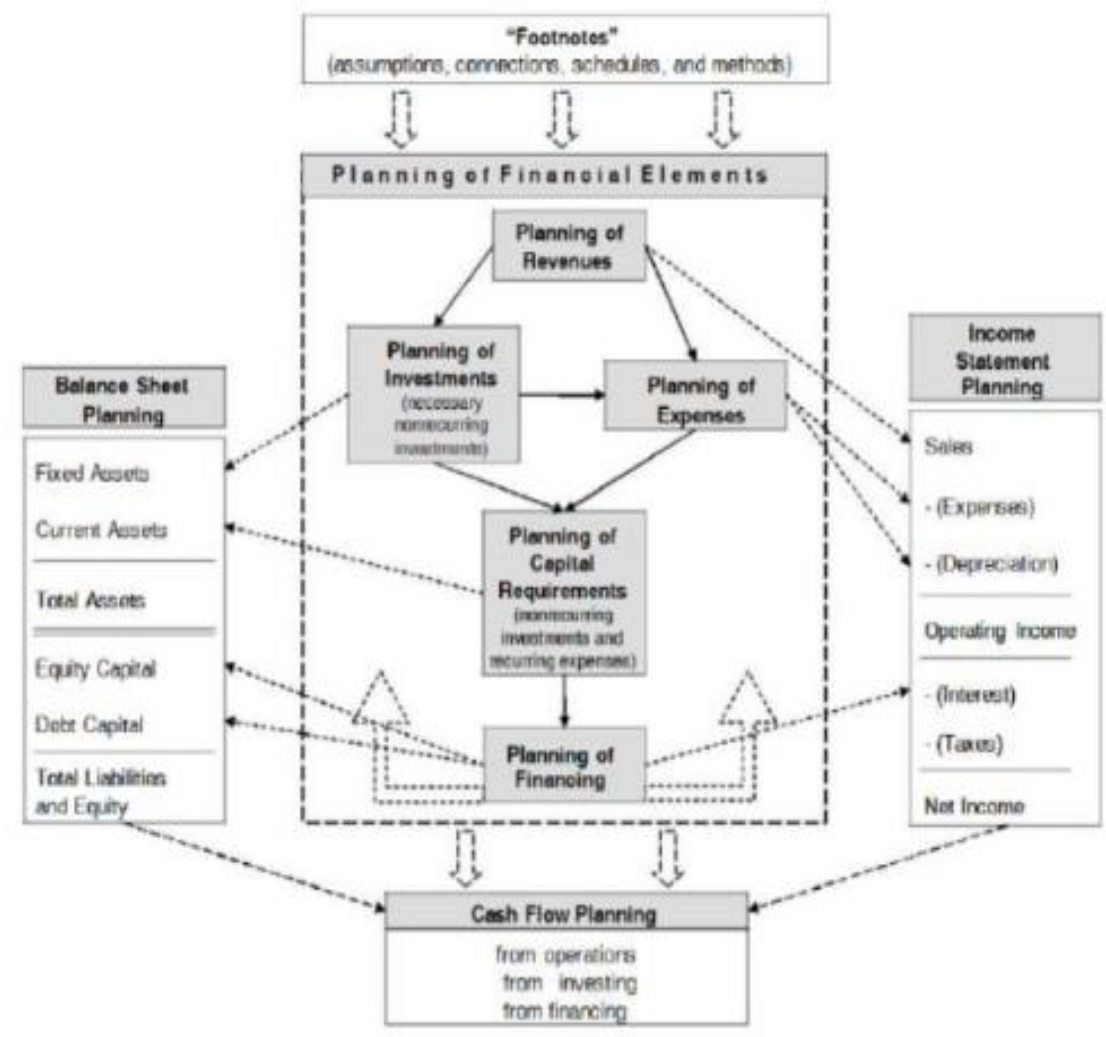

Gambar 3.1 Financial Element Planning of PT. Zaps Teknologi

The elements of financial planning PT. Zaps Teknologi consists of income planning, cost planning, investment planning as well as capital requirements planning and financing planning.

Tabel 3.1 Income planning

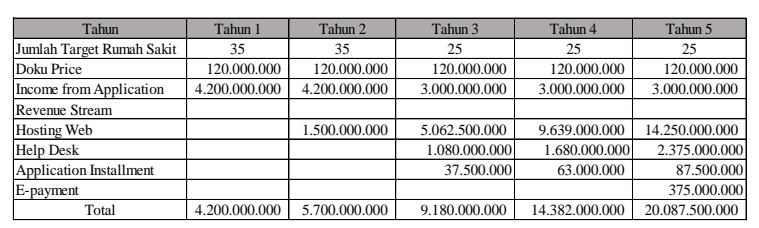

Income statement by PT. Zaps Technology includes the company's 5-year plan to earn revenue that has several sources other than application sales, namely improving application services in the form of features that will be embedded in the application, to capture the company's financial strategy, the company should have added value in financial planning, (Kusuma et al., 2021). 
Tabel 3.2 Cost Planning

\begin{tabular}{|c|c|c|c|c|c|c|}
\hline Uraian & & Tahun 1 & Tahun 2 & Tahun3 & Tahun 4 & Tahun 5 \\
\hline Pemasaran & $\mathrm{Rp}$ & 935.500 .000 & Rp 1.406 .025 .000 & Rp 1.768.700.000 & Rp 2.249.125.000 & Rp 2.694.500.000 \\
\hline Operasional & $\mathrm{Rp}$ & 1.068 .421 .860 & Rp 1.590.0088.847 & Rp 1.788.781.000 & Rp 2.389.683.157 & Rp 3.105.475.676 \\
\hline Sumber Daya Manusia & $\mathrm{Rp}$ & 1.764 .010 .800 & Rp 1.764 .010 .800 & Rp 2.066.713.200 & Rp 2.706 .828 .400 & Rp 3.048.831.920 \\
\hline Manajemen Risiko & $\mathrm{Rp}$ & 12.000 .000 & $\begin{array}{ll}\operatorname{Rp} & 12.000 .000 \\
\end{array}$ & \begin{tabular}{|ll} 
Rp & 12.000 .000 \\
\end{tabular} & \begin{tabular}{ll|}
$\operatorname{Rp}$ & 12.000 .000 \\
\end{tabular} & $\begin{array}{ll}\text { Rp } & 12.000 .000 \\
\end{array}$ \\
\hline Total Biaya & $\mathrm{Rp}$ & 3.779 .932 .660 & Rp 4.772.044.647 & \begin{tabular}{|l|l} 
Rp 5.636.194.200 \\
\end{tabular} & Rp 7.357.636.557 & Rp 8.860.807.596 \\
\hline
\end{tabular}

PT. Zaps Teknologi has 4 cost elements in cost planning which are marketing, operational and HR as well as risk management costs, in the course of the company's business the focus is on product development (Doku) so that operational costs and HR have a larger portion than marketing costs, this is in accordance with the details above costs.

Investment planning PT. Zaps Technology must reflect that positive and healthy financial behavior leads to higher levels of financial well-being. (Lidwina et al., 2020) this is reflected in the investment analysis of PT. Zaps Teknologi. Investment planning consists of the company's capital structure and the fulfillment of that capital.

Tabel 3.3 Capital Needs
\begin{tabular}{|l|ll|}
\hline \multicolumn{3}{|c|}{ Kebutuhan Modal } \\
\hline Total Capital Expenditure & $\mathrm{Rp}$ & 1.719 .015 .766 \\
\hline Total Operating Expenditure & $\mathrm{Rp}$ & 3.779 .932 .660 \\
\hline Total Kebutuhan Modal & $\mathrm{Rp}$ & 5.498 .948 .426 \\
\hline
\end{tabular}

Capital comes from the founders and investors who invest their capital, the composition of the large capital consists of $70 \%$ from the four founders and $30 \%$ from investors, angel investors are chosen by PT. Zaps Teknologi to invest in the company. The level of efficiency of capital planning is an effort to increase the probability of (Sutjiadi et al., 2020) the company so that the capital will be used to meet the needs of capital expenditure and operating expenditure.

\begin{tabular}{|c|c|c|c|c|c|c|c|}
\hline Keterangan & & Tahun 1 & & Tahun 2 & Tahun 3 & Tahun 4 & Tahun 5 \\
\hline Penjualan & $\mathrm{Rp}$ & 4.200.000.000 & $\mathrm{Rp}$ & 5.700 .000 .000 & Rp 9.180.000.000 & Rp14.382.000.000 & Rp 20.087 .500 .000 \\
\hline \multicolumn{8}{|c|}{ 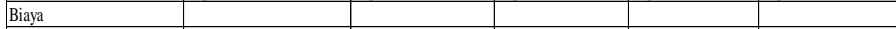 } \\
\hline \begin{tabular}{|l|} 
Total Biaya Marketing \\
\end{tabular} & $\mathrm{Rp}$ & 935.500 .000 & $\mathrm{Rp}$ & 1.281 .025 .000 & Rp 1.478.700.000 & Rp 1.869.125.000 & 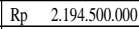 \\
\hline \multicolumn{8}{|l|}{ Biaya Operasional } \\
\hline Total Biaya Operasional & $\mathrm{Rp}$ & 1.068 .421 .860 & $\mathrm{Rp}$ & 1.590 .008 .847 & Rp 1.788 .781 .000 & Rp 2.389.683.157 & 3.105 .475 .676 \\
\hline \multicolumn{8}{|l|}{ Biaya SDM } \\
\hline Total Biaya SDM & $\mathrm{Rp}$ & 1.764 .010 .800 & $\mathrm{Rp}$ & 1.831 .964 .400 & Rp 2.066.713.200 & Rp 2.706.828.400 & 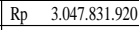 \\
\hline \multicolumn{8}{|l|}{ Biaya Manajemen Risiko } \\
\hline Asuransi & $\mathrm{Rp}$ & 12.000 .000 & $\mathrm{Rp}$ & 12.000 .000 & 12.000 .000 & 12.000 .000 & 12.000 .000 \\
\hline \multicolumn{8}{|l|}{ Total Biaya Manajemen } \\
\hline Risiko & $\mathrm{Rp}$ & 12.000 .000 & $\mathrm{Rp}$ & 12.000 .000 & 12.000 .000 & 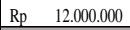 & 12.000 .000 \\
\hline Total Biaya Biaya & $\mathrm{Rp}$ & 3.779 .932 .660 & $\mathrm{Rp}$ & $\begin{array}{l}4.714 .998 .247 \\
\end{array}$ & Rp 5.346.194.200 & Rp 6.977.636.557 & 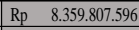 \\
\hline EBITDA & $\mathrm{Rp}$ & $\begin{array}{l}420.067 .340 \\
\end{array}$ & $\mathrm{Rp}$ & 985.001 .753 & Rp 3.833 .805 .800 & Rp 7.404.363.443 & $\begin{array}{lll}\text { Rp } & 11.727 .692 .404 \\
\end{array}$ \\
\hline \multicolumn{8}{|l|}{ Biaya Penyusutan } \\
\hline $\begin{array}{l}\text { Total Biaya Penyusutan dan } \\
\text { Amortisasi }\end{array}$ & $\mathrm{Rp}_{\mathrm{p}}$ & & & & $\begin{array}{lll}\mathrm{Rp} & 31.800 .000\end{array}$ & & 31.800 .000 \\
\hline \begin{tabular}{|l|} 
Amortisasi \\
EBIT \\
\end{tabular} & $\mathrm{Rp}$ & $\begin{array}{r}31.8000 .000 \\
388.267 .340 \\
\end{array}$ & $\begin{array}{l}\mathrm{Kp} \\
\mathrm{Rp} \\
\end{array}$ & \begin{tabular}{|r|}
31.800 .0000 \\
953.201 .753 \\
\end{tabular} & \begin{tabular}{lr|} 
Rp & 30.8000 .000 \\
Rp & 3.802 .005 .800 \\
\end{tabular} & 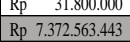 & $\begin{array}{ll}\text { Rp } & 11.695 .892 .404 \\
\end{array}$ \\
\hline Pajak & $\mathrm{Rp}$ & 85.418 .815 & $\mathrm{Rp}$ & 209.704 .386 & $\begin{array}{ll}\text { Rp } & 760.401 .160 \\
\end{array}$ & Rp 1.474.512.689 & 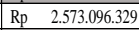 \\
\hline Laba Setelah Pajak / EAT & $\mathrm{Rp}$ & 302.848 .525 & $\mathrm{Rp}$ & $\begin{array}{l}743.497 .367 \\
\end{array}$ & Rp 3.041.604.640 & Rp 5.898.050.754 & 9.122 .796 .075 \\
\hline
\end{tabular}

In the table above it can be illustrated that the profit earned was smaller in the early years this was because the company focused on sales to hospitals, the 3 rd to 5 th year the increase in profit was increasingly visible, this happened because in those years the effect of the increase services with various existing features are able to boost the company's revenue.

Tabel 3.5 Balance sheet planning

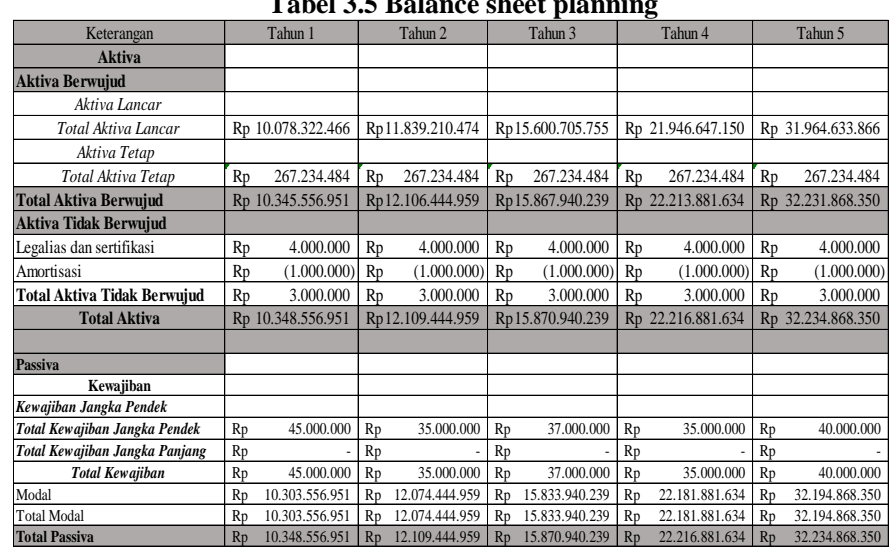


PT. Zaps Teknologi shows the movement of current assets which increases every year this is in accordance with the transactions carried out by the company, while in liabilities there are accounts payable in line with the business activities of the company.

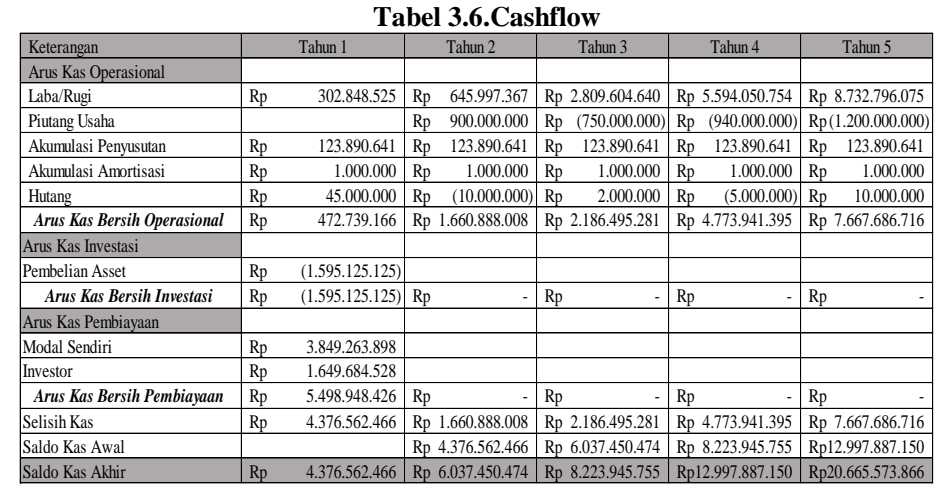

The acceptance of cash along with its mutations and changes are presented in the cash flow planning, cash flow planning of PT. Zaps Technology consists of 3 activities, namely operations, investment and financing. For operations sourced from profit/loss on accounts receivable and others, mutations that occur due to company business transactions, for investment sourced from the purchase of the company's initial assets and for financing from capital. Cash planning data according to the table above.

The feasibility of the calculated investment is based on the prepared financial statements. Financial statements are prepared for five years including income statement, balance sheet, and cash flow (Azmal, Negoro, Yanuar, \& Syah, 2019). Futhermore, the calculation of investment analysis consists of ROI, NPV, PP and IRR.(Hanifatul et al., 2020) and (Benjamin B. Gansel, 2000.)

Tabel 3.7 Return on Investment

\begin{tabular}{|}
\begin{tabular}{|c|cr|c|c|}
\hline \multicolumn{2}{|c|}{ Laba } & Investasi & ROI \\
\hline Tahun 1 & Rp & 302.848 .525 & Rp 5.498.948.426 & $6 \%$ \\
\hline Tahun 2 & Rp & 645.997 .367 & Rp 5.498.948.426 & $12 \%$ \\
\hline Tahun 3 & Rp 2.809 .604 .640 & Rp 5.498.948.426 & $51 \%$ \\
\hline Tahun 4 & Rp 5.594 .050 .754 & Rp 5.498.948.426 & $102 \%$ \\
\hline Tahun 5 & Rp & 8.732 .796 .075 & Rp 5.498.948.426 & $159 \%$ \\
\hline
\end{tabular}
\end{tabular}

ROI is a calculation that is used as a parameter to calculate an investment that is feasible or not, the results of the calculation for ROI can be seen in the picture above.
The data shows that within 5 years the company has experienced an increase, this is influenced by an increase in revenue due to the development of DOKU application products.

\begin{tabular}{|c|c|c|c|c|c|c|}
\hline \multicolumn{7}{|c|}{\begin{tabular}{l|r}
\multicolumn{2}{|c}{ Tabel 3.8 NPV, PP, PI and IRR } \\
Biaya awal & 5.498 .948 .426
\end{tabular}} \\
\hline \multicolumn{3}{|c|}{ BI Rate } & \multicolumn{4}{|c|}{$3,50 \%$} \\
\hline & \multicolumn{2}{|c|}{ Proceed (Rp) } & \multicolumn{2}{|c|}{$\begin{array}{c}\text { Cumulative Proceed } \\
(\mathbf{R p})\end{array}$} & \multicolumn{2}{|c|}{\begin{tabular}{|c} 
Discounted Proceed \\
(Rp)
\end{tabular}} \\
\hline Biaya awal & $\mathrm{Rp}$ & (5.498.948.425) & & & & \\
\hline Tahun 1 & $\mathrm{Rp}$ & 302.848 .525 & $\mathrm{Rp}$ & 302.848 .525 & $\mathrm{Rp}$ & 292.248 .827 \\
\hline Tahun 2 & $\mathrm{Rp}$ & 645.997 .367 & $\mathrm{Rp}$ & 948.845 .893 & $\mathrm{Rp}$ & 623.387 .459 \\
\hline Tahun 3 & $\mathrm{Rp}$ & 2.809 .604 .640 & $\mathrm{Rp}$ & 3.758 .450 .533 & $\mathrm{Rp}$ & 2.711 .268 .478 \\
\hline Tahun 4 & $\mathrm{Rp}$ & 5.594 .050 .754 & $\mathrm{Rp}$ & 9.352 .501 .287 & $\mathrm{Rp}$ & 5.398 .258 .978 \\
\hline \multirow[t]{2}{*}{ Tahun 5} & $\mathrm{Rp}$ & 8.732 .796 .075 & $\mathrm{Rp}$ & 18.085 .297 .362 & $\mathrm{Rp}$ & 8.427 .148 .212 \\
\hline & \multicolumn{2}{|c|}{ Perusahaan } & \multicolumn{2}{|c|}{ Pembanding } & \multicolumn{2}{|c|}{ Kesimpulan } \\
\hline NPV & & 58.478 .730 & $\mathrm{Rp}$ & 5.498 .948 .426 & & Layak \\
\hline Payback Period & & 2,5 & & ebih Cepat & & Layak \\
\hline Profitability Index & & 2,85 & & ih Besardari 1 & & Layak \\
\hline IRR & & $34 \%$ & Lebih & besar dari 3,50\% & & Layak \\
\hline
\end{tabular}

For NPV, it is used to calculate the difference between the present value of cash flows in and the current value of cash flows out in a certain period. NPV is a reference in determining whether a company's finances are feasible or not, PT. Zaps Teknologi for five years has an NPV calculation of Rp. $10,158,478,730$. with a BI Rate of $3.5 \%$ This shows that the existing investment is very good because it exceeds the costs incurred, which is Rp. 5,498,948,426,- The payback period is achieved in the 2 nd year and 5th month, The faster the investment returns, the better the company is running, Payback Period (PP) is the time needed to return the value of the investment that has been issued. To calculate PP, the parameter used is the calculation of the payback period 
of PT. Zaps Teknologi which is intended to find out how long the investment spent will return to the company. The discount rate that produces NPV $=0$ is the Internal Rate of Return, IRR is the maximum capital that a business can afford. Calculation of PT. Zaps Technology has a positive value of $34 \%$, this shows that the profits generated are greater when compared to the capital that has been issued.

Tabel 3.9 Ratio of PT. Zaps Teknologi

\begin{tabular}{|l|c|c|c|c|c|}
\hline \multicolumn{1}{|c|}{ Uraian } & Tahun 1 & Tahun 2 & Tahun 3 & Tahun 4 & Tahun 5 \\
\hline Rasio Likuiditas & & & & & \\
\hline Current Ratio & 224 & 338 & 422 & 627 & 799 \\
\hline Quick Ratio & 222 & 336 & 419 & 624 & 797 \\
\hline Cash Ratio & 97 & 172 & 222 & 371 & 517 \\
\hline Rasio Profitabilitas & & & & & \\
\hline Net Profit Margin & $10 \%$ & $15 \%$ & $39 \%$ & $49 \%$ & $56 \%$ \\
\hline Return on Asset & $2,93 \%$ & $5,33 \%$ & $17,70 \%$ & $25,18 \%$ & $27,09 \%$ \\
\hline Return on Equity & $3 \%$ & $5 \%$ & $18 \%$ & $25 \%$ & $27 \%$ \\
\hline Rasio Solvabilitas & & & & & \\
\hline Debt to Equity Ratio & $0,44 \%$ & $0,29 \%$ & $0,23 \%$ & $0,16 \%$ & $0,12 \%$ \\
\hline Debt to Asset Ratio & $0,43 \%$ & $0,29 \%$ & $0,23 \%$ & $0,16 \%$ & $0,12 \%$ \\
\hline
\end{tabular}

The calculation of the analysis of the financial performance of PT Zaps Teknologi can be seen in 3.8 where the calculation of the ratio that describes the financial condition of the company, the ratio consists of the liquidity ratio, profitability ratio and solvency ratio. The three ratios are indicators of the company's development assessment using data from financial statements during the accounting period. This ratio is used by company management in deciding company policies.

\section{CONCLUSION}

Based on investment analysis, calculation, financial analysis and income planning that has been calculated (ROI, NPV, PP and IRR), it can be concluded that the investment planned by PT. Zaps Technology for 5 years is feasible to implement. PT. Zaps Teknologi has good financial performance which allows investors to consider investing their capital.

Acknowledgement: None

Conflict of Interest: None

Source of Funding: None

\section{REFERENCES}

1. Azmal, R., Negoro, D. A., Yanuar, T., \& Syah, R. (2019). The Influence Cash Position Analysis over Debt to Equity Ratio , Return On Assets , And Inventory Turnover on Dividend Payout Ratio: Consumer Goods Companies in Indonesia Stock Exchange 2012-2017 Case Study.

2. Benjamin, B. Gansel. (n.d.). Toward a Framework of Financial Planning in New Venture Creation. 49(0).

3. Hanifatul, R., Tantri Yanuar Rahmat Syah, Semerdanta Pusaka, and D. R. (2020a). Financial Implementation for Start-up Business. 350-353.

4. Hanifatul, R. , Tantri Yanuar Rahmat Syah, Semerdanta Pusaka, and D. R. (2020b). Financial Implementation for Start-up Business Home Care Applicationss. 350-353.

5. Kusuma, A., Syah, T. Y., \& Indradewa, R. (2021). Implementation Of Financial Strategy Business Plan Arena Corner. American International Journal of Business Management Vol 4(07).

6. Kwarti, C., Marsiwi, K., Yanuar, T., Syah, R., Pusaka, S., \& Indradewa, R. (2020). Investment Feasibility Analysis in Financial Aspects of Startup Business In Lifestyle Combining Barbershop And Coffee shop Over PT . Jeeva Work Corporation. Journal of Multidisciplinary Academic, 03(04).

7. Lidwina, F. A. Pijoh, Rhian Indradewa, T. Y. R. S. (2020). Financial Literacy, Financial Behaviour and Financial Anxiety: Implication for Financial Well Being of Top Management Level Employees. Journal of Multidisciplinary Academic, 04(06).

8. Prihambodo, F. P., Yanuar, T., Syah, R., Indradewa, R., \& Fajarwati, D. (2020). Investment Feasibility Analysis in Financial Aspects of Noor Halal Minimarket Business Development Over Islamic Schools. Journal of Multidisciplinary Academic, Vol 04(03). 
9. Royyadi, C. S., Nofierni, M. A. (2021). Development Model of Indonesian National Health Insurance ( BPJS ) Flow Process at Hospital Hermina Ciruas Using Lean Hospital Approach. Vol. 5, No. 1, 2021.

10. Sutjiadi, A., Yanuar, T., Syah, R., Indradewa, R., \& Fajarwati, D. (2020). Working Capital Planning at PT Kelola Lingkungan Kita as an Effort to Increase
Probability. Journal of Multidisciplinary Academic, Vol 04(06), 421-425.

How to cite this article: Wafiq Z, Hamdi E, Syah TYR et.al. Investment analysis of startups company PT. Zaps Teknologi Service application of BPJS. International Journal of Research and Review. 2021; 8(8): 504-509. DOI: https://doi.org/10. 52403/ijrr.20210868

$* * * * * *$ 